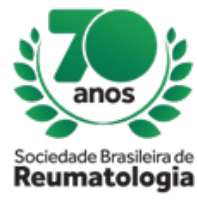

\title{
IGA VASCULITIS OR POST-STREPTOCOCCAL VASCULITIS? NINE-YEARS EXPERIENCE IN A NEW PEDIATRIC RHEUMATOLOGY CENTER IN NORTHEAST BRAZIL
}

\begin{abstract}
GABRIELA COUTINHO GONDIM DA JUSTA (HOSPITAL GERAL DE FORTALEZA, FORTALEZA, CE, Brasil), FRANCISCO AFRANIO PEREIRA NETO (HOSPITAL GERAL WALDEMAR DE ALCÂNTARA, FORTALEZA, CE, Brasil), MARIANA NOBRE DE ALMEIDA DIAS (HOSPITAL GERAL WALDEMAR DE ALCÂNTARA, FORTALEZA, CE, Brasil), REBECCA AZULAY MARTINS GONDIM (CENTRO UNIVERSITÁRIO UNICHRISTUS, FORTALEZA, CE, Brasil), ANA BEATRIZ ALMEIDA DA CUNHA (CENTRO UNIVERSITÁRIO UNICHRISTUS, FORTALEZA, CE, Brasil), LARISSA ELIAS PINHO (HOSPITAL GERAL DE FORTALEZA, FORTALEZA, CE, Brasil), MÍRIA PAULA VIEIRA CAVALCANTE (HOSPITAL GERAL DE FORTALEZA, FORTALEZA, CE, Brasil), MARCO FELIPE CASTRO DA SILVA (HOSPITAL GERAL DE FORTALEZA, FORTALEZA, CE, Brasil), CARLOS NOBRE RABELO-JUNIOR (HOSPITAL GERAL DE FORTALEZA, FORTALEZA, CE, Brasil)
\end{abstract}

\section{BACKGROUND}

IgA vasculitis (IgAV) is the most frequent primary vasculitis of childhood, characterized by small vessels inflammation, with predominance of cutaneous, articular, gastrointestinal and renal manifestations. In most cases there is relation with triggering factors, mainly those of infectious origin. Although it's a benign and self-limiting condition in almost all cases, it may rarely require short- and long-term drug treatment, especially when there is major organ involvement.

\section{MATERIALS AND METHODS}

Retrospective, descriptive and observational cohort study performed at the pediatric rheumatology unit of a tertiary hospital in Ceará. Patients medical records with a diagnosis of IgAV between May 2010 and April 2019 (EULAR / PRES / PRINTO criteria), starting disease before 18 years-old, were evaluated. Data were collected in May 2019 and analyzed through percentages and Fisher's exact test.

\section{RESULTS}

A total of 63 individuals were included, of which $33(52.4 \%)$ were female. The mean age at diagnosis and mean follow-up duration were 8.7 (2.1 - 16.9) and $2.8(0-7.6)$ years, respectively. Regarding to clinical manifestations at diagnosis, palpable purpura predominating in lower limbs ( $100 \%$ of cases) and arthritis (87.3\%) were most common findings. Gastrointestinal involvement was described in 38 (60.3\%) patients, being more frequent: abdominal pain (94.7\%), nausea and/or vomiting (50\%) and bleeding (31.6\%). Renal changes were found in only nine $(14.3 \%)$ patients, mainly hematuria $(100 \%)$ and proteinuria $(33.3 \%)$. Among all, 29 (46\%) patients reported a possible trigger infectious before diagnosis, especially infections of upper airways and impetigo. It's noteworthy that serological evidence of previous streptococcal infection (ASLO positive) was detected in 43/63 (72.9\%) patients. About treatment, 52 (82.5\%) received medication at diagnosis, mainly corticosteroids (73.1\%). Corticosteroid use were associated with gastrointestinal involvement at diagnosis $(p<0.001)$, especially cases with bleeding $(p=0.0019)$. Patients diagnosed before 10 years had higher rate of gastrointestinal complains $(p=0.0328)$, being too the subgroup with disease recurrences (3/63). Of total, 59 (93.7\%) patients achieved complete remission, without any medication at the last visit.

\section{CONCLUSION}

Data regarding clinical manifestations were similar to those in literature. The high prevalence of clinical or laboratorial streptococci evidence in the present study as trigger strongly suggests $\mathrm{S}$. pyogenes role in IgAV pathophysiology. This supports clinical-serological evaluation in all suspeteced patients, and can also be useful as diagnostic criteria. Patients younger than 10 years, especially with abdominal 
involvement, should be promptly evaluated for disease severity and need for short-term corticosteroid therapy. 